\title{
SISTEM INFORMASI STRATEGI PEMASARAN PRODUK DENGAN METODE MARKET BASKET ANALYSIS DAN SALES FORECASTING: SWALAYAN KOTA MAKASSAR
}

\author{
Rizal Bakri, Ardiansyah Halim \& Niken Probondani Astuti \\ Sekolah Tinggi llmu Ekonomi Makassar Bongaya \\ E-mail: rizal.bakri@stiem-bongaya.ac.id
}

\begin{abstract}
ABSTRAK
Salah satu sektor penyimpanan data real time yang besar adalah pada sektor pemasaran dalam bentuk transaksi penjualan, harga, dan ketersediaan barang yang disimpan dalam database di supermarket tertentu. Jumlah supermarket dengan sistem kasir digital memungkinkan menyimpan data transaksi penjualan. Penelitian ini bertujuan untuk merancang suatu aplikasi yang berisi dua metode analisis statistik, yaitu Market Basket Analysis dan Sales Forecasting menggunakan paket shiny dashboard di Market Basket Analysis menunjukkan berbagai fitur yang dapat memudahkan pelaku bisnis dalam mengoptimalkan tata letak produk di rak-rak toko yang merupakan ringkasan produk, rules table, scatter plot, graph, matrix dan grouphed, serta Parallel coordinats. Di samping itu, Sales Forecasting menampilkan berbagai fitur yang terdiri dari deskripsi jumlah stok barang, jumlah barang yang terjual, capital, profit, frekuensi tertinggi barang yang dijual dan nilai parameter predictions untuk periode berikutnya.
\end{abstract}

Kata Kunci: Marketing strategy, Market Basket Analysis, Sales Forecasting, shinydashboard

\begin{abstract}
One of the large real time data storage sectors is in the marketing sector in the form of sales transactions, prices, and availability of goods stored in databases in certain supermarkets. The amount of supermarkets with the digital cash register system allow storing sales transaction data. Therefore this research aims to designed an application that contains two statistical analysis methods, namely Market Basket Analysis and Sales Forecasting using shinydashboard package in Market Basket Analysis Menu shows various features that can facilitate business actors in optimizing product layout in a store shelves i.e. summary products, rules table, scatter plot, graph, matrix and grouphed, and Parallel coordinats. While the sales forecasting menu showsvarious features i.e. a description of the number of stock items, the number of items sold, capital, profit, the highest frequency of goods sold, and the value of parameterpredictions for the next periods.
\end{abstract}

Keywords: Marketing strategy, Market Basket Analysis, Sales Forecasting, shinydashboard 


\section{Rizal Bakri}

\section{Ardiansyah Halim \\ Niken Probondani Astuti}

\section{PENDAHULUAN}

Pesatnya perkembangan dunia usaha pada era globalisasi saat ini telah membawa kemajuan teknologi komputasi dan media penyimpanan yang mendorong manusia untuk mengumpulkan dan menyimpan data dengan jumlah yang besar. Fenomena tersebut dapat terjadi dalam berbagai bidang kehidupan termasuk dalam dunia bisnis sehingga peran data sains sangat dibutuhkan. Salah satu sektor penyimpanan data real time yang jumlahnya begitu besar berada pada sektor pemasaran berupa transaksi penjualan, harga, maupun ketersediaan barang yang tersimpan di dalam database. Adanya big data ini, para pebisnis memanfaatkan data tersebut untuk mencari informasi guna meningkatkan strategi pemasaran.

Market Basket Analysis merupakan salah satu tipe analisis data yang paling sering digunakan oleh para data saintist diberbagai sektor industri diantaranya sektor pemasaran untuk melihat asosiasi antar objek. Teknik ini digunakan untuk menganalisis isi keranjang belanja guna mendapatkan informasi produk apa saja yang paling sering dibeli sekaligus oleh para konsumen. Hasil dari analisis dapat digunakan strategi dalam menjalankan bisnis, seperti rekomendasi tata letak barang dan mengoptimalkan ketersediaan cadangan produk yang berelasi agar seimbang. Setelah produk-produk terseleksi, sales forecasting dapat digunakan untuk mengamati pola penjualan, pola keuntungan, dan perancanaan penjualan.

Saat ini Kota Makassar termasuk salah satu kota dengan tingkat perekonomian yang sedang maju, salah satunya berada di sektor pemasaran. Tingkat pertumbuhan ekonomi Kota Makassar Tahun 2017 sebanyak 8,23\% (BPS,2018). Selain pasar tradisional, swalayan merupakan salah satu sektor pemasaran yang banyak diminati oleh masyarakat kota Makassar. Jumlah swalayan dengan sistem kasir digital memungkinkan melakukan penyimpanan data transaksi penjualan. Namun tak sedikit pimpinan atau penentu kebijakan swalayan di Kota Makassar memanfaatkan data tersebut agar memberi informasi yang berharga. Hal ini ditandai dengan masih banyaknya swalayan di Kota Makassar yang memiliki tata letak barang dan persediaan barang yang kurang optimal. Untuk mengatasi masalah tersebut, salah satu upaya yang dapat dilakukan adalah menciptakan teknologi baru dalam meningkatkan manajemen strategi pemasaran melalvi pemanfaatan statistika komputasi berbasis website.

Software statistik mengalami kemajuan akibat perkembangan kebutuhan analisis terhadap data yang begitu besar (big data). Salah satu software statistik yang sedang trend adalah 
software R Studio. Software ini dapat diperoleh dengan gratis dan bersifat open source. Selain itu, R Studio dilengkapi dengan paket-paket statistik yang lengkap dan memiliki kemampuan komputasi yang tinggi. R Studio dapat juga digunakan dalam pembuatan aplikasi baik berbasis dekstop maupun website dengan menggunakan paket Shiny Dashboard. Oleh karena itu, penelitian ini bertujuan untuk membangun suatu aplikasi sistem informasi untuk strategi pemasaran dengan metode Market Basket Analysis dan Sales Forecasting.

\section{LANDASAN TEORI \\ Pola Belanja Konsumen}

Pola belanja konsumen dapat diprediksi berdasarkan tingkat kepentingan. Masyarakat yang datang ke pasar tradisonal adalah konsumen yang ingin membeli dalam jumlah banyak (grosir) sementara konsumen yang ingin membeli dalam jumlah yang sedikit lebih memilih pasar modern seperti supermarket. Banyaknya masyarakat yang datang ke pasar modern dapat membentuk suatu pola belanja yang terstruktur. Pola belanja konsumen dapat diartikan sebagai bentuk struktur dari kegiatan belanja konsumen yang pasti. Dari pola belanja yang dapat diprediksi inilah pembuat keputusan dapat membuat strategi pemasaran yang lebih efektif (Gunawan, 2015).

\section{Market Basket Analysis}

Market Basket Analysis adalah teknik matematis yang biasa digunakan oleh marketing profesional untuk menyatakan kesamaan antara produk individu atau kelompok individu. Istilah Market Basket Analysis sendiri datang dari kejadian yang sudah sangat umum terjadi di dalam pasar swalayan, yakni ketika para konsumen memasukkan semua barang yang mereka beli kedalam keranjang (basket). Informasi mengenai produk-produk yang biasanya dibeli secara bersama-sama oleh para konsumen dapat memberikan "wawasan" berupa informasi yang sangat berharga bagi para pengelola swalayan untuk menaikkan laba bisnisnya (Albion Reserach, 2007).Selain dalam sektor pemasara produk, Metode Market Basket Analysis juga dapat digunakan diberbagai sektor industri lainnya diantaranya Penggunaan Metode Market Basket Analysis dalam bidang ekologi yaitu melihat hubungan kimia di Lingkungan yang telah dilakukan oleh Samecka-cymerman, et. al. (2010). Sektor lain misalnya dalam dunia medis yaitu untuk mengidentifikasi hubungan antara gejala dan penyakit, atau antara obat dan efek samping yang telah dilakukan oleh Belyi $E$, et. al. (2016).

Associaton rule merupakan salah satu teknik data mining yang digunakan dalam Market Basket Analysis. Association rule (aturan asosiatif) akan menemukan pola tertentu yang 


\section{Rizal Bakri}

\section{Ardiansyah Halim}

\section{Niken Probondani Astuti}

mengasosiasikan data yang satu dengan data yang lain. Untuk mencari association rule dari suatu kumpulan data, tahap pertama yang harus dilakukan adalah mencari frequent item setter lebih dahulu. Frequent item set adalah sekumpulan item yang sering muncul secara bersamaan. Setelah semua pola frequent item set ditemukan, barulah mencari aturan asosiatif atau aturan keterkaitan yang memenuhi syarat yang telah ditentukan. Pada algoritma ini, penentuan kandidat yang mungkin muncul adalah dengan cara memperhatikan minimum support dan confidence. Pengertian tentang support dan confidence dapat dijelaskan sebagai berikut: Support merupakan suatu ukuran yang menunjukkan seberapa besar tingkat dominasi suatu item/itemset dari keseluruhan transaksi. Ukuran ini menentukan apakah suatu item/itemset layak untuk dicari confidence-nya (misal, dari keseluruhan transaksi yang ada, seberapa besar tingkat dominasi (frequent) yang menunjukkan bahwa item A dan B dibeli bersamaan). Adapun formula untuk menghitung nilai support item A dan B adalah:

$$
\text { Support }=\mathrm{P}(\mathrm{A} \cap \mathrm{B})=\frac{\text { jumlah transaksi yang memuat } \mathrm{A} \text { dan } \mathrm{B}}{\text { total jumlah transaksi }}
$$

Confidence merupakan suatu ukuran yang menunjukkan hubungan antar dua item secara conditional (misal, seberapa sering item B dibeli jika pembeli membeli item A). Adapun formula untuk menghitung confidence aturan asosiatif $\mathrm{A} \rightarrow \mathrm{B}$ adalah:

$$
\text { Confidence }=\mathrm{P}(\mathrm{B} \mid \mathrm{A})=\frac{\text { Support }(\mathrm{A} \cap \mathrm{B})}{\mathrm{P}(\mathrm{A})}
$$

(Irliana \& Vydia, 2013)

Aplikasi Market Basket Analysis dibangun menggunakan beberapa paket $R$ yaitu paket arules (Hahsler et. al, 2018) dan paket arulesViz (Hahsler M \& Chelluboina S, 2018) yang terdapat dalam database Cran $\mathrm{R}$.

\section{Sales Forecasting}

Produksi berdasarkan ramalan penjualan adalah penting, sehingga tidak menimbulkan produksi yang berlebih untuk menghindari pemborosan atau kerugian. Menurut Swastha (2008), sales forecasting (ramalan penjualan) adalah tingkat penjualan yang diharapkan dapat dicapai pada masa yang akan datang dengan mendasarkan pada data penjualan riil dimasa lampau. Sedangkan menurut Rizkiyani (2014) sales forecasting adalah kegiatan penyusunan ramalan tentang sifat atau ciri-ciri penjualan dari suatu pokok yang dihasilkan 
oleh suatu perusuhaan termasuk jumlah, kualitas serta harga dari produk pada waktu tertentu dimasa yang akan datang.

Metode statistik yang digunakan pada penelitian ini adalah metode Exponantial Smoothing. Metode ini merupakan metode rata-rata bergerak yang memberikan bobot lebih kuat pada data terakhir dari pada data awal. Hal ini menjadi sangat berguna jika perubahan terkahir pada data lebih merupakan akibat dari perubahan aktual (seperti pola musiman) daripada hanya fluktuasi acak saja dengan ramalan rata-rata bergerak saja sudah cukup (Paramita \& Tanuwiajaya, 2010). Penelitian ini menggunakan paket Forecast yang telah disiapkan dalam database R dengan fungsi ets dan forecast (Hyndman et. al, 2018).

\section{Shiny Dashboard Package}

Paket Shiny dashboard digunakan untuk membangun aplikasi ini. Paket ini berjalan pada aplikasi statistik yang sedang populer saat ini yaitu aplikasi $R$ yang dikembangkan oleh Ross Ihaka dan Robert Gentleman pada tahun 1992 dari Departemen Statistika, Univeristas Auckland, Selandia Baru (Ihaka R \& Gentleman R, 1996). Paket ini dikembangkan oleh para kontributor $\mathrm{R}$ dengan bantuan beberapa paket lain seperti paket shiny dan paket lainnya (Chang \& Borges, 2018). Kelebihan paket ini adalah mampu membuat aplikasi interface berbasis komputasi dan dapat dijalankan secara online diantaranya (1) penelitian yang dilakukan oleh Mazzara, et. al. (2017) tentang web interaktif untuk memilih penanda yang akurat kombinasi data omics yang dapat diakses secara online melalui halaman http://combiroc.eu/, (2) penelitian yang dilakukan oleh Villaseñor-Derbez, et. al. (2018) tentang aplikasi user friendly untuk mengevaluasi kefektifan cadangan laut yang dapat diakses secara online melalui halaman https://turfeffect.shinyapps.io/marea/.

\section{METODE PENELITIAN}

\section{Jenis Penelitian}

Jenis penelitian pada penelitian ini adalah kuantitatif, terdiri dari deskripsi terhadap pola pembelanjaan konsumen dan pola ketersediaan barang untuk menemukan informasi yang berharga dari sekumpulan data dengan teknik data mining menggunakan rancangan aplikasi yang akan dibangun.

\section{Teknik Pengumpulan Data}

Jenis data pada penelitian ini adalah data sekunder yaitu data yang sudah tersedia dalam perangkat tertentu tanpa membangkitkan data baru. Oleh karena itu peneliti cukup melakukan observasi dengan mengamati langsung aktivitas-aktivitas data transaksi di dalam database komputer kasir. Selanjutnya data transaksi konsumen dan data harga produk 


\section{Rizal Bakri}

\section{Ardiansyah Halim}

\section{Niken Probondani Astuti}

dapat diperoleh menggunakan software Navicat Premium. Data yang sudah diperoleh dari database akan di ekspor ke format Excel.

\section{Analisis Data}

Dalam penelitian ini, metode analisis data akan dijelaskan berdasarkan tujuan penelitian. Adapun tahapan analisis data pada penelitian ini ditunjukkan pada Gambar 1. Berikut tahapan analisis data yang digunakan:

\section{Database dan Data Processing}

Tahapan pertama dalam penelitian ini adalah akses Database dan Data Processing. Data transaksi penjualan dan harga setiap barang akan diambil dari database kasir. Selanjutnya, dilakukan persiapan data (data processing) untuk analisis berikutnya.

\section{Market Basket Analysis}

Tahapan kedua adalah Market Basket Analysis. Metode statistik yang akan digunakan adalah metode data mining dengan algoritma Assotiation rule yang merupakan metode untuk melihat frekuensi item produk yang terjual. Hasil dari metode ini dapat pula digunakan untuk menentukan posisi yang tepat dalam penempatan produk dalam rak penjualan. Adapun peubah yang akan digunakan pada metode ini adalah peubah transaksi penjualan $(Y)$ yang terdiri dari sekumpulan item produk yang dibeli oleh konsumen. Software yang akan digunakan untuk analsisi ini adalah aplikasi R Studio.

\section{Sales Forecasting}

Tahapan berikutnya adalah Sales Forecasting yang digunakan untuk melihat peramalan manajemen kevangan dalam strategi pemasaran. Pada bagian ini, analisis data yang digunakan adalah analisis data dengan pendekatan kuantitatif deskriptif yaitu metode Exponenital Smoothing. Adapun peubah yang digunakan adalah Waktu dalam bulan ( $\dagger$ ), Jumlah produk (X1), harga produk awal (X2), dan harga jual (X3). Software yang akan digunakan untuk analsis ini adalah aplikasi R Studio.

\section{Perancangan Aplikasi}

Tujuan utama dalam penelitian ini adalah perancangan Aplikasi. Aplikasi yang akan dibangun akan memudahkan pengguna dalam menganalisis metode Market Basket Analysis dan Sales Forecasting. Setelah data dianalisis mengggunakan kedua metode tersebut, selanjutnya dirancang aplikasi interface menggunakan software R Studio dengan paket Shiny dashboard berdasarkan tampilan menu aplikasi pada Gambar 2. 


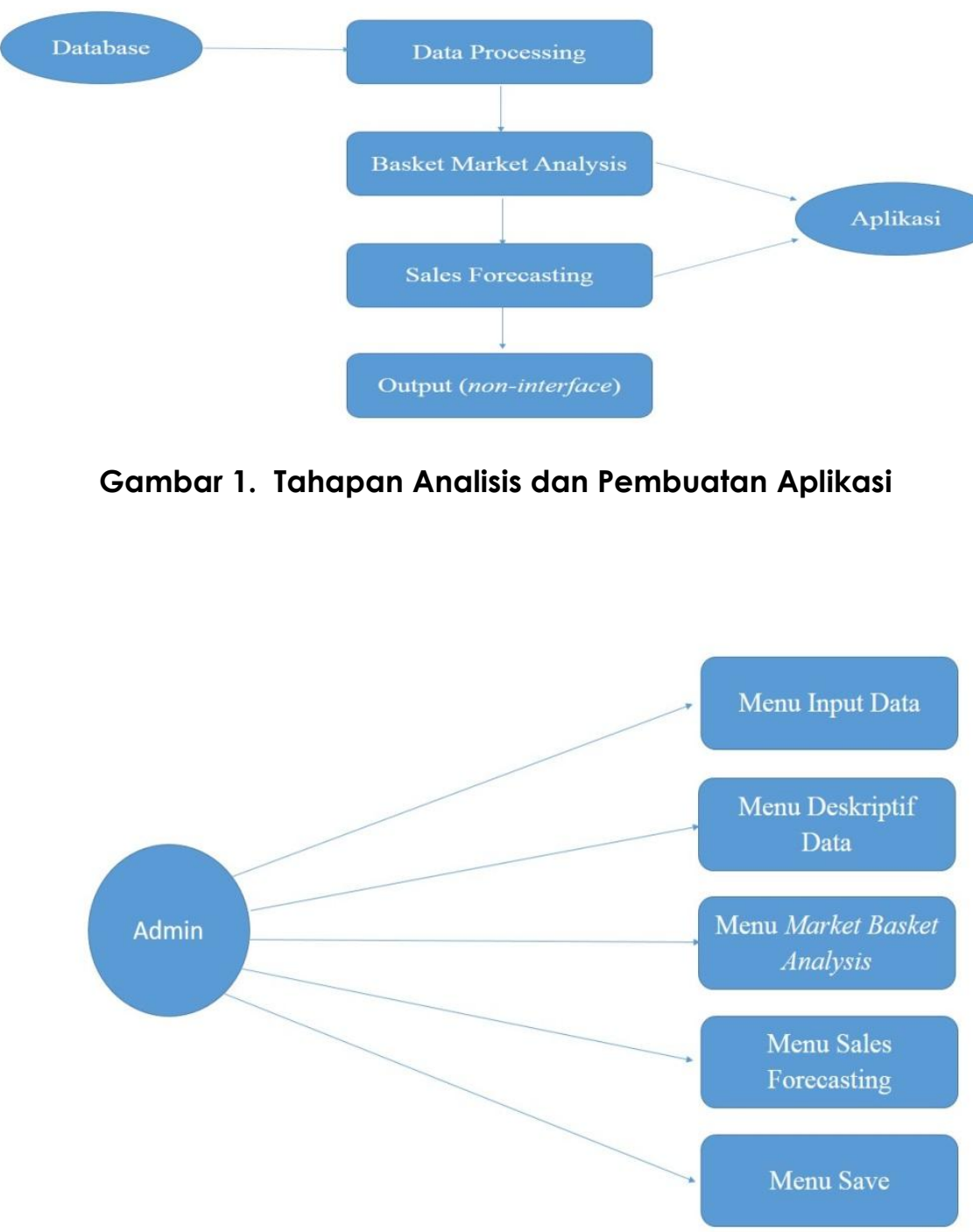

Gambar 2. Usecase Aplikasi

Gambar 2 menunjukkan prototype dashboard aplikasi. Dashboard Aplikasi memuat beberapa fitur yang di dalamnya terdiri dari berbagai fasilitas analisis statistik seperti fitur import data berupa file csv, fitur deskripitf data masing-masing metode, Fitur market basket analysis, fitur sales forecasting, dan fitur simpan hasil analisis.

\section{Validasi Aplikasi}

Aplikasi interface yang telah dibuat akan dilakukan validasi output. Langkah ini dilakukan dengan cara membandingkan hasil output pada olah data R Studio (non-interface) dan hasil olah data aplikasi yang telah dibuat (interface) dengan Shinydashboard. Selanjutnya, aplikasi akan diinstal pada komputer admin/penentu kebijakan swalayan. 
Rizal Bakri

Ardiansyah Halim

Niken Probondani Astuti

\section{Data}

\section{Aplikasi}

\section{Output}

\section{Gambar 3. Tahapan Validasi Aplikasi}

\section{HASIL DAN PEMBAHASAN}

\section{Data Processing dan Dashboard Aplikasi}

Aplikasi dirancang menggunakan data simulasi yang di peroleh dari paket Arulesdan paket Forecast dengan struktur data ditunjukkan pada Tabel 1 dan Tabel 2. Tabel 1 merupakan struktur data pembelian produk semua pelanggan atau struk pembelanjaan, sebagai contoh misalnya pelanggan pertama membeli produk $A, B, C . D, H$, dan $L$ dalam waktu yang sama, begitupun untuk pelanggan berikutnya. Sedangkan Tabel 2 merupakan tabel data penjualan yang terdiri dari beberapa parameter seperti tanggal, nama produk yang dijual, harga awal atau modal tiap produk, Jumlah Stok Produk yang tersedia, Harga Jual masing-masing produk, dan Jumlah masingmasing produk yang terjual. Kedua tabel tersebut umumnya tersimpan di dalam database swalayan.

Tabel 1. Struktur Data untuk Market Basket Analysis

\begin{tabular}{cl}
\hline Pelanggan & \multicolumn{1}{c}{ Item Produk } \\
\hline 1 & $\{A, B, C, D, H, L\}$ \\
2 & $\{A, B, C, D, H, L, M, R, X, Z, W, F\}$, \\
$\cdot$ & $\cdot$ \\
$\cdot$ & $\cdot$ \\
\hline
\end{tabular}

Tabel 2. Struktur Data untuk Sales Forecasting

\begin{tabular}{cccccc}
\hline Tanggal & Produk & $\begin{array}{c}\text { Modal } \\
\text { Produk }\end{array}$ & $\begin{array}{c}\text { Stok } \\
\text { Produk }\end{array}$ & $\begin{array}{c}\text { Harga Jual } \\
\text { Satuan }\end{array}$ & $\begin{array}{c}\text { Jumlah } \\
\text { Terjual }\end{array}$ \\
\hline $2018-05-16$ & G & 66,26 & 21 & 70,33 & 20 \\
$2018-05-13$ & R & 67,35 & 25 & 71,29 & 20 \\
$\cdot$ &. &. &. &. &. \\
. &. &. &. &. &. \\
$\mathrm{n}$ & $\mathrm{P}$ & $\mathrm{V}$ & $\mathrm{q}$ & $\mathrm{s}$ & $\mathrm{O}$ \\
\hline
\end{tabular}


Dashboard aplikasi sistem informasi strategi pemasaran produk telah dibuat menggunakan aplikasi R Studio dengan bantuan paket shinydashboard dan beberapa paket lainnya. Aplikasi ini dapat diakses melalui halaman https://stiem.shinyapps.io/AnalisisMarketing/

\section{Menu Market Basket Analysis}

Menu ini bertujuan untuk melihat analisis data tentang pola susunan produk dalam rak. Gambar 4 menunjukkan tampilan utama menu Market Basket Analysis yang terdiri dari beberapa settingan parameter.

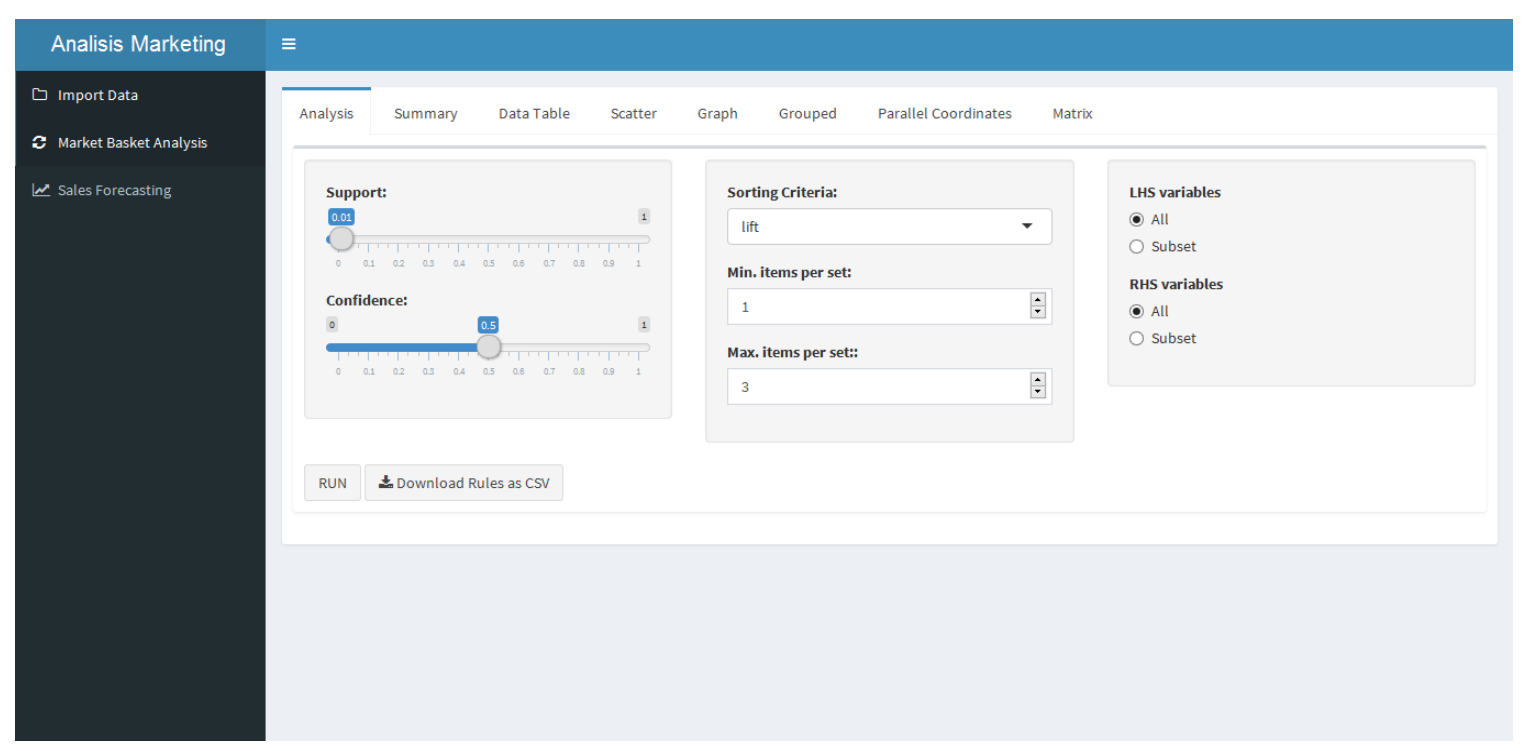

Gambar 4. Tampilan Utama Market Basket Analysis

\section{Summary}

Bagian summary menunjukan analisis deskriptif tentang pembelanjaan produk. Analisis deskriptif yang terdapat pada bagian ini adalah jumlah transaksi penjualan, frekuensi item produk yang paling banyak terjual, serta nilai statistik lainnya seperti rataan, median, dan lainnya yang ditunjukkan pada gambar 5 .

\section{Data Table}

Data table merupakan bagian inti dari Market Basket Analysis. Pada bagian ini menunjukkan hasil olahan data tentang asosiasi kombinasi item produk yang tepat berdasarkan pola belanja konsumen.

Pada analisis ini terdapat beberapa statistik hitung yang menjadi pertimbangan dalam mengambil keputusan dalam menyusun item produk yang tepat berdekatan dalam rak yang sama. Statistik hitung yang paling utama dalam analisis ini adalah nilai lift yang menunjukkan bahwa semakin tinggi nilai lift suatu pasangan item (role) maka peluang 


\section{Rizal Bakri}

\section{Ardiansyah Halim}

\section{Niken Probondani Astuti}

terjadinya pasangan tersebut untuk terjual semakin tinggi. Hasil pada penelitian ini lebih interaktif karena output dari metode Market Basket Analysisditampilkan dengan user friendlyyang dilengkapi dengan berbagai fitur output analisis statistik seperti nilai Support, nilai Confidence, nilai lift, dan lainnya (Gambar 6).

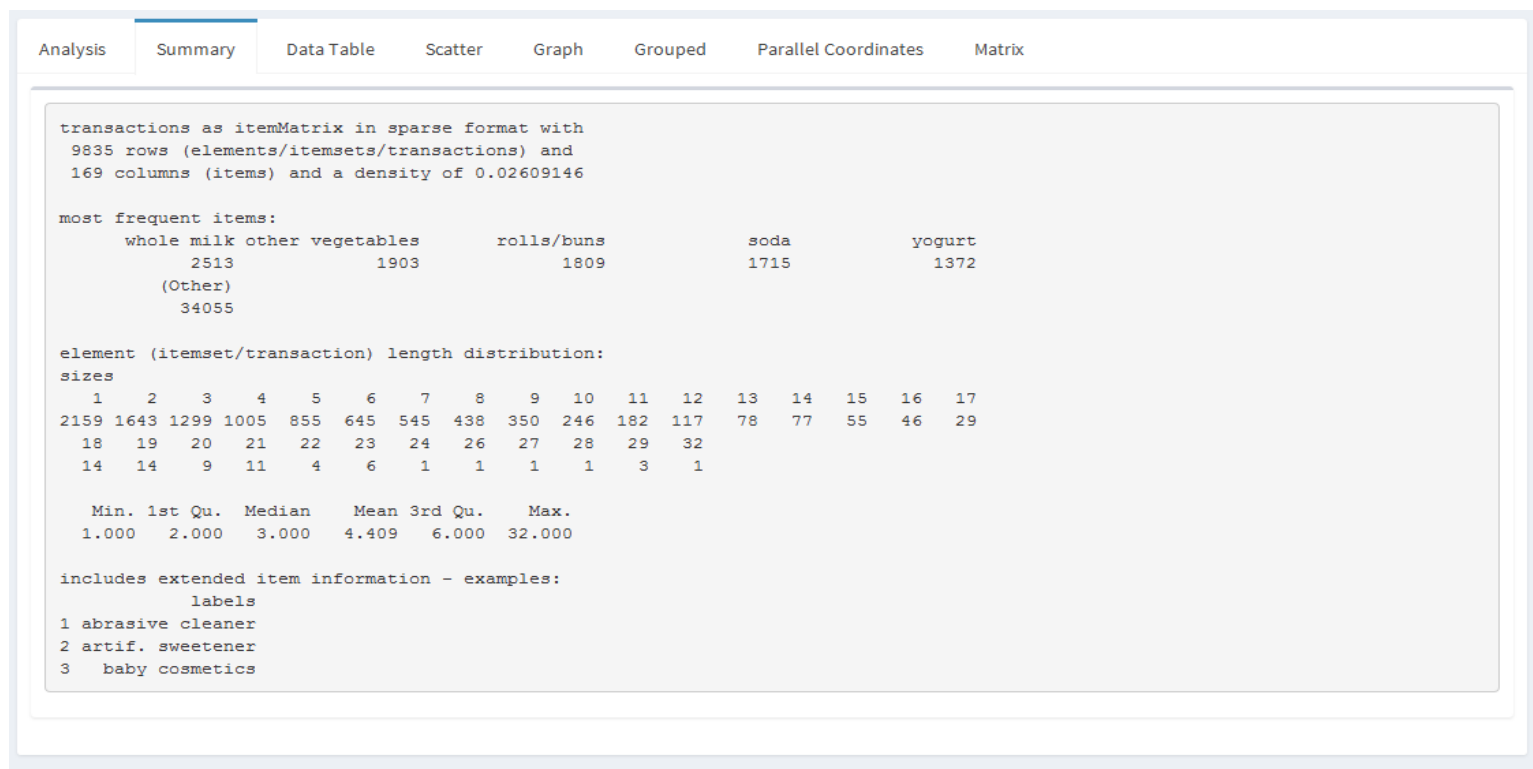

Gambar 5. Tampilan Output Summary

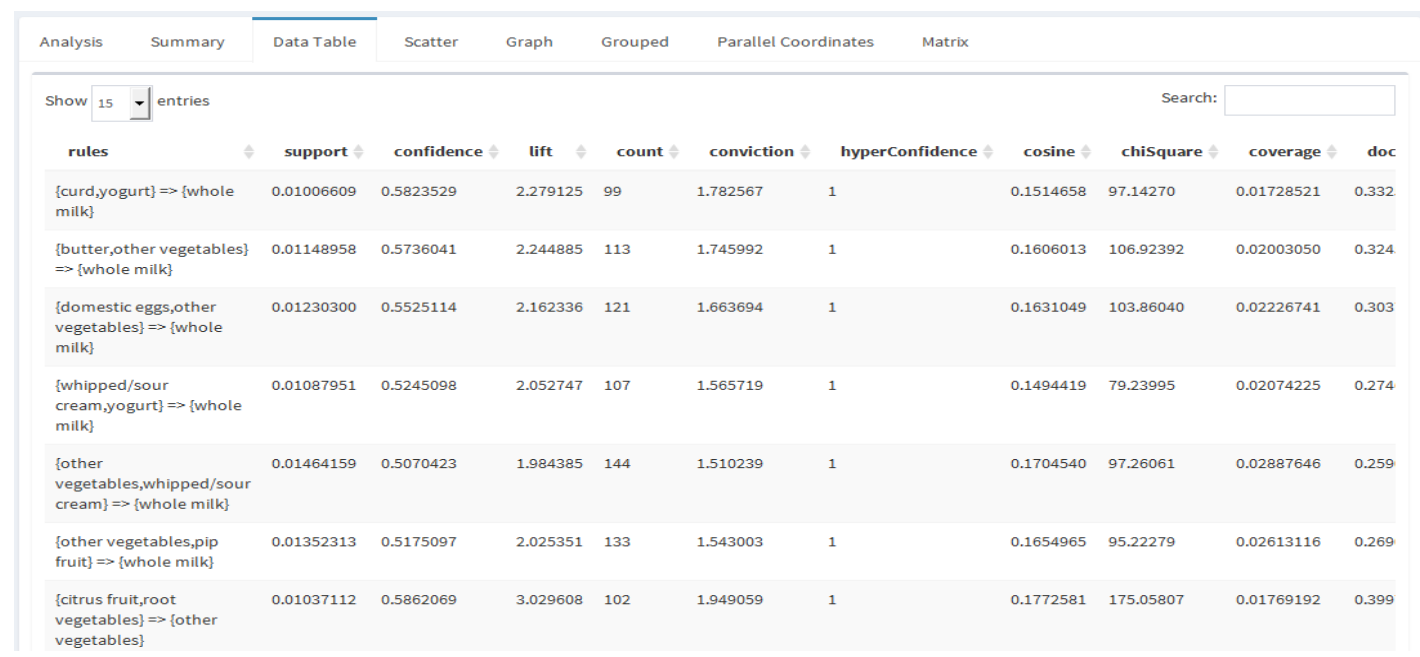

Gambar 6. Data Table Hasil Asosiasi Pasangan Kombinasi Item

\section{Scatter Plot}

Scatter plot merupakan grafik yang menunjukkan pergerakan data dua variabel kuantitatif disertai variabel lain. Pada analisis ini variabel yang digunakan untuk membuat scatter plot 
adalah nilai support dan confidence serta variabel lift. Parameter support dan confidence merupakan nilai parameter yang menentukan asosiasi kombinasi item-item produk. Support (nilai penunjang) merupakan persentase kombinasi item dalam database, sedangkan confidence (nilai kepastian) merupakan kuatnya hubungan antar item dalam suatu pasangan item (role). Sebagai contoh misalnya: $\{$ roti, mentega $\} \rightarrow\{$ susu\} (support $=40 \%$, confidence $=50 \%$ ) yang artinya, Seseorang konsumen yang membeli roti dan mentega punya kemungkinan 50\% untuk juga membeli susu, sedangkan $40 \%$ dari seluruh transaksi yang ada memuat ketiga item produk tersebut.

Gambar 7 menunjukkan scatter plot variabel support dan variabel confidence yang menunjukkan bahwa semakin tinggi lift pasangan kombinasi item (role) cenderung memiliki nilai support dan confidence yang rendah.

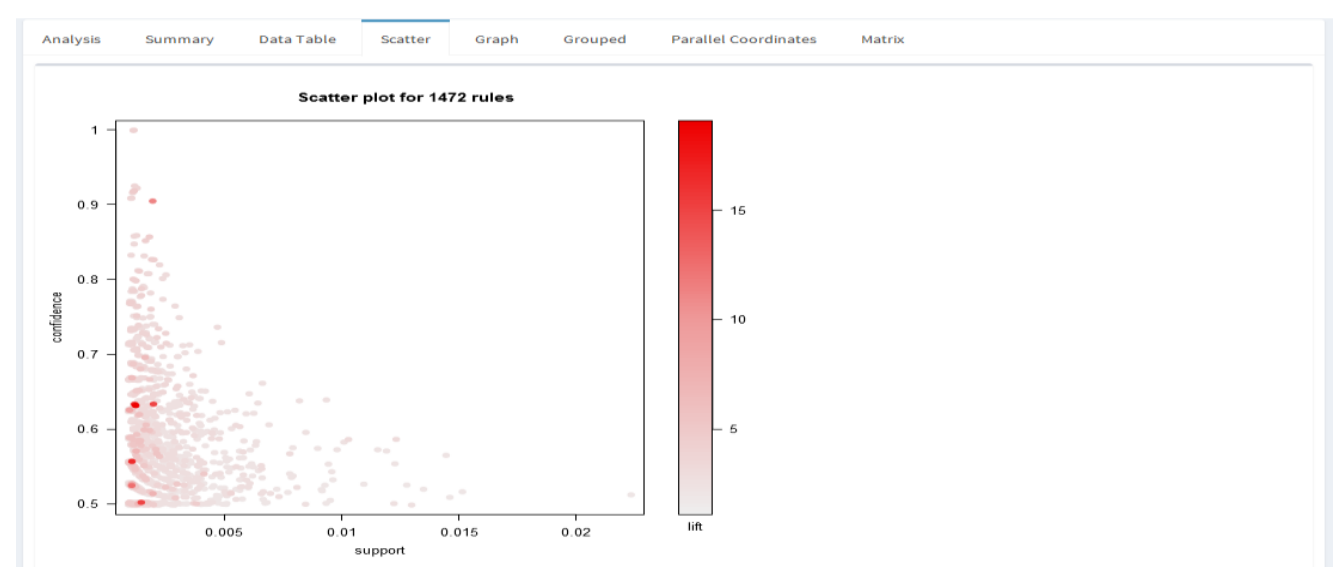

Gambar 7. Scatter Plot

\section{Graph}

Asosiasi antar pasangan kombinasi items dapat pula diperlihatkan dalam bentuk graph. Gambar 8 merupakan graph dari 100 pasangan kombinasi item (rules) yang menujukkan asosiasi atau keterkaitan antar item dalam pasangan-pasangan kobinasi item. Warna yang terang menunjukkan pasangan kombinasi item (rules) yang cenderung memiliki nilai lift tinggi.

\section{Matrix dan Grouped}

Penggerombolan kombinasi pasangan item (rules) dapat dilihat pada output Matrix dan Grouped. Gambar 9 menunjukkan 15 kelompok kombinasi pasangan item berdasarkan Matriks jarak yang telah dibuat dengan metode Jacard. Tujuan dari pengelompokan ini adalah untuk menemukan kombinasi pasangan item mana saja yang dapat diletakaan dalam rak yang berdekatan berdasarkan pola belanja konsumen. 


\section{Rizal Bakri}

\section{Ardiansyah Halim}

Niken Probondani Astuti

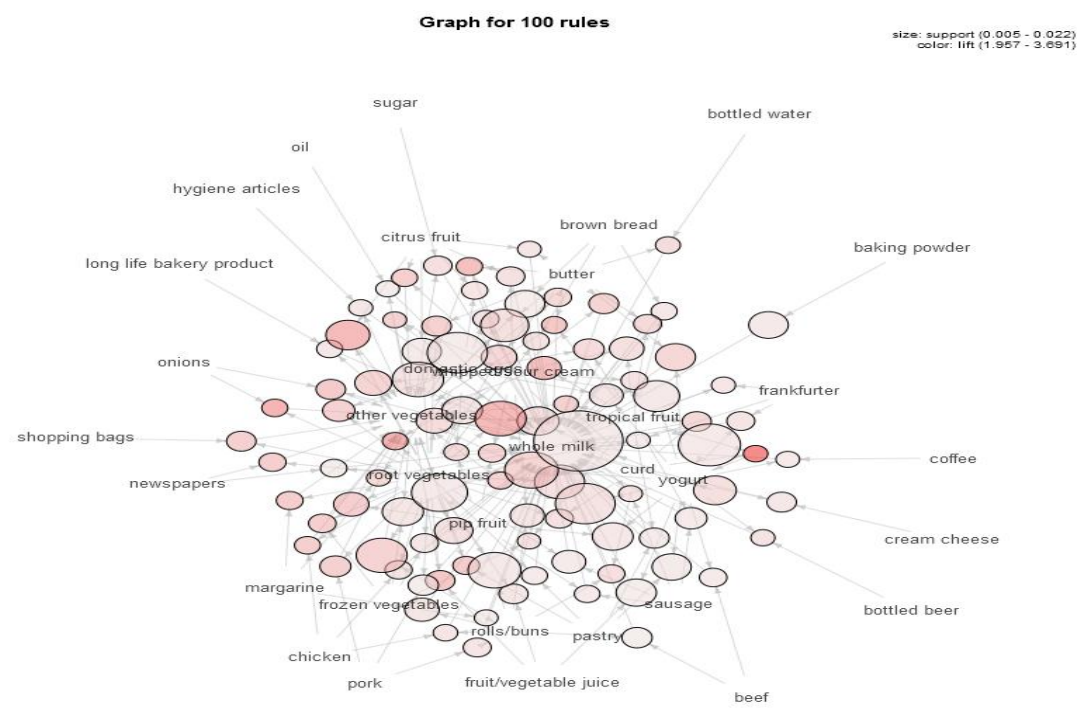

Gambar 8. Graph 100 rules

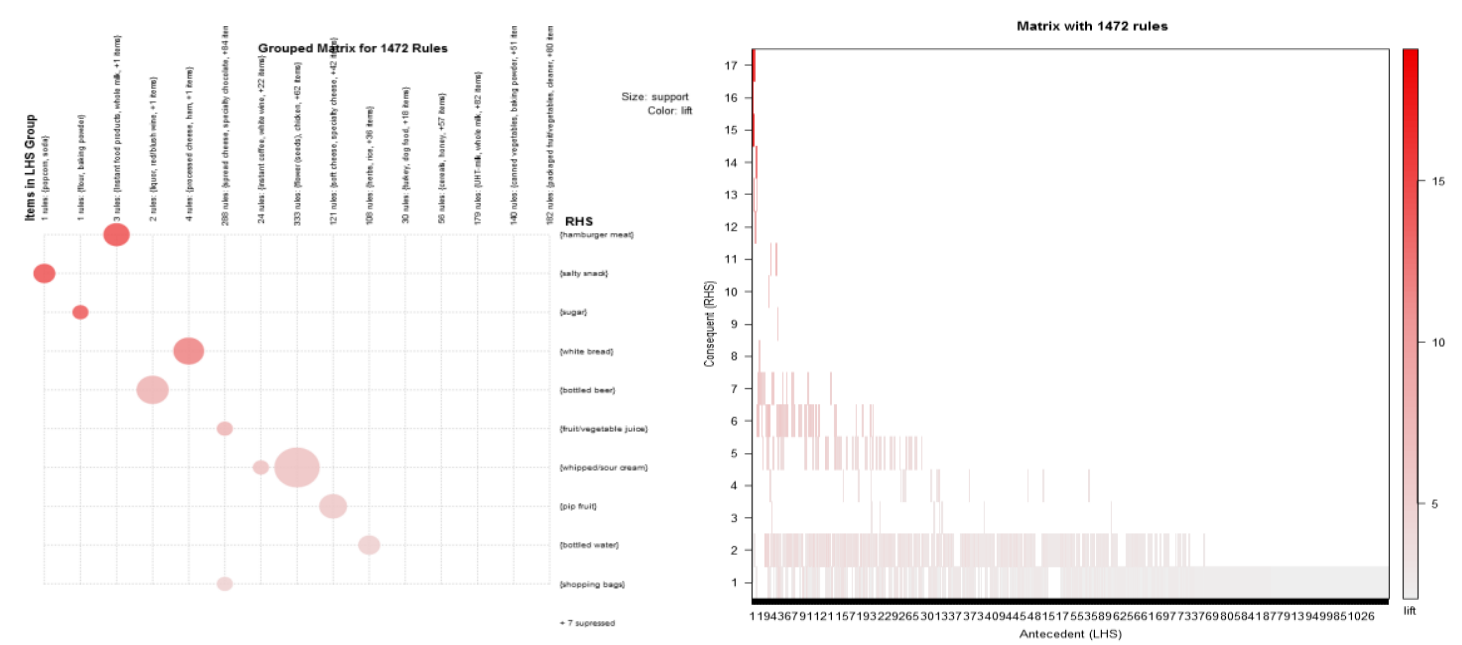

Gambar 9. Matrix dan Grouped

\section{Parallel coordinats}

Parallel coordinat didesain untuk visualisasi multidimensi data dimana setiap dimensi ditunjukkan oleh sumbu kordinat yang saling berhubungan. 


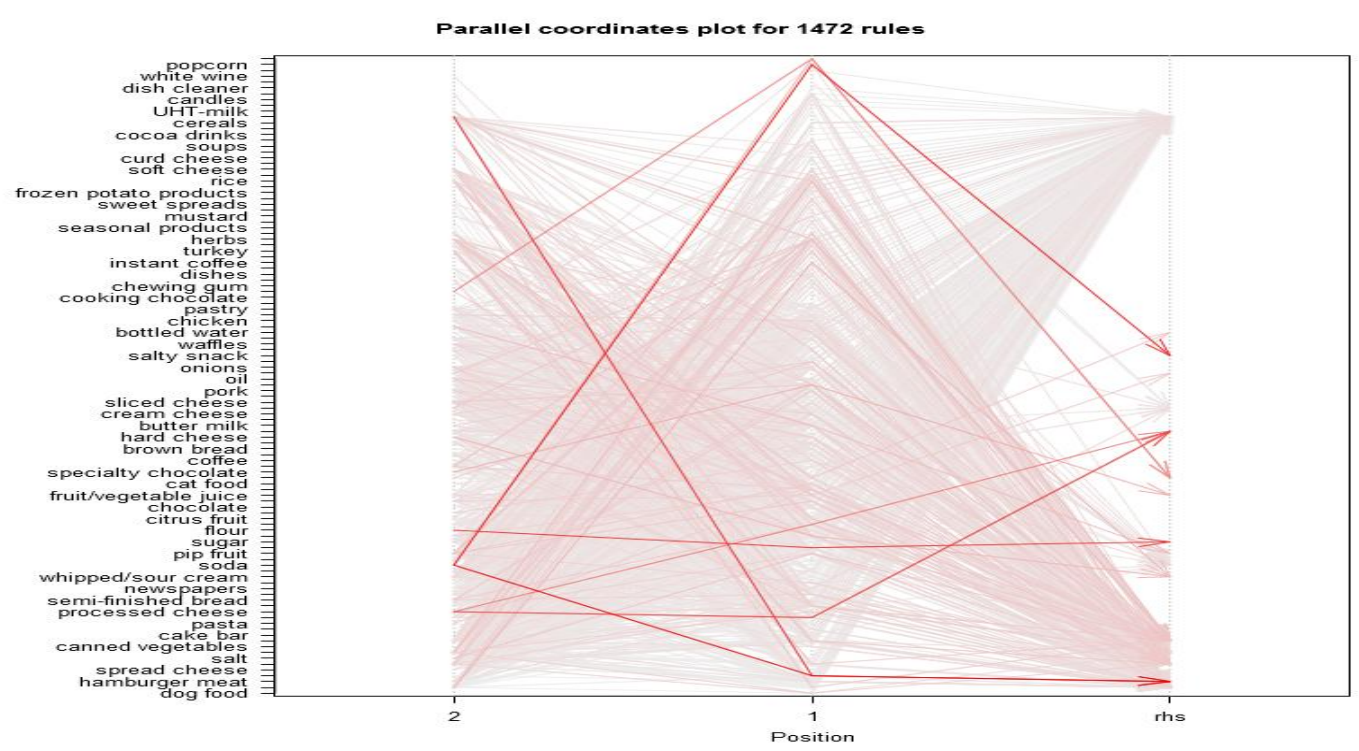

Gambar 10. Parallel coordinats

Ketebalan garis penghubung representasikan oleh nilai support dan intensitas warna direpresentasikan oleh nilai confidence. Parallel coordinats digunakan sebelumnya dalam penggerombalan kombinasi pasangan item yang telah dijelaskan sebelumnya. Dalam statistik, Parallel coordinats identik dengan analisis profil, yaitu suatu analisis yang digunakan untuk melihat kemiripan objek berdasarkan dimensi data yang digambarkan oleh sebuah garis yang ditunjukkan pada Gambar 10.

\section{Menu Sales Forecasting}

Menu selanjutnya dalam aplikasi strategi pemasaran ini adalah menu Sales Forecasting. Menu ini menunjukkan analisis deskriptif dan analisis peramalan data data penjualan seperti stok barang, harga awal atau modal, harga jual, jumlah barang yang laku, serta keuntungan.

\section{Summary Product}

Informasi tentang data penjualan produk dapat dilihat pada output summary items. Gambar 11 merupakan summary items yang menunjukkan data stok barang, jumlah terjual, keuntungan, rata-rata harga produk, rata-rata harga jual, serta rata-rata nilai ramalan keuntungan untuk peridode beriktnya berdasarakan nama produk yang dipilih dan dengan rentang waktu yang dapat ditentukan pada aplikasi. Selain deskripsi data penjualan, bagian ouput ini juga menampilkan sebuah grafik tentang produk yang paling sering terjual atau laris berdasarkan parameter-parameter penjualan. 
Rizal Bakri

Ardiansyah Halim

Niken Probondani Astuti

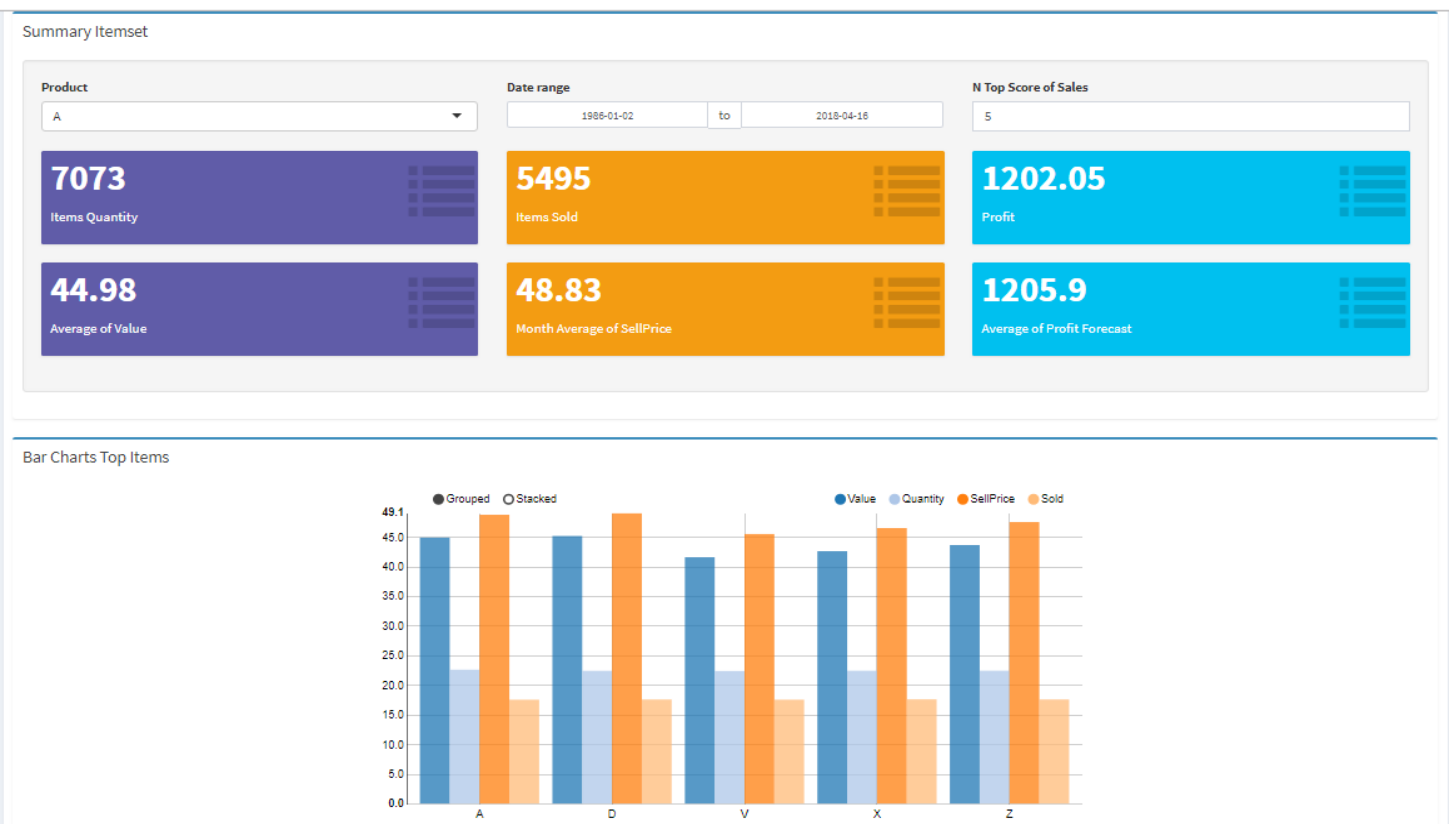

Gambar 11. Tampilan Summary Items Sales Forecasting

\section{Comodity}

Output comodity terdiri dari dua analisis utama yaitu grafik pergerakan data produk dan Analisis Peramalan produk dengan metode Exponantial Smoothing beserta grafiknya. Gambar 12 menunjukkan grafik pergerakan data produk berdasarakan parameter penjualan. Grafik yang dibuat berbentuk interaktif sehingga nilai masing-masing titik dan parameternya dapat terlihat saat mengarahkan kursor ke grafik tersebut. Selain itu, bagian ini juga terdapat menu pilihan lain seperti memilih produk, parameter penjualan yang akan ditampilkan plotnya, dan rentang waktu grafik.

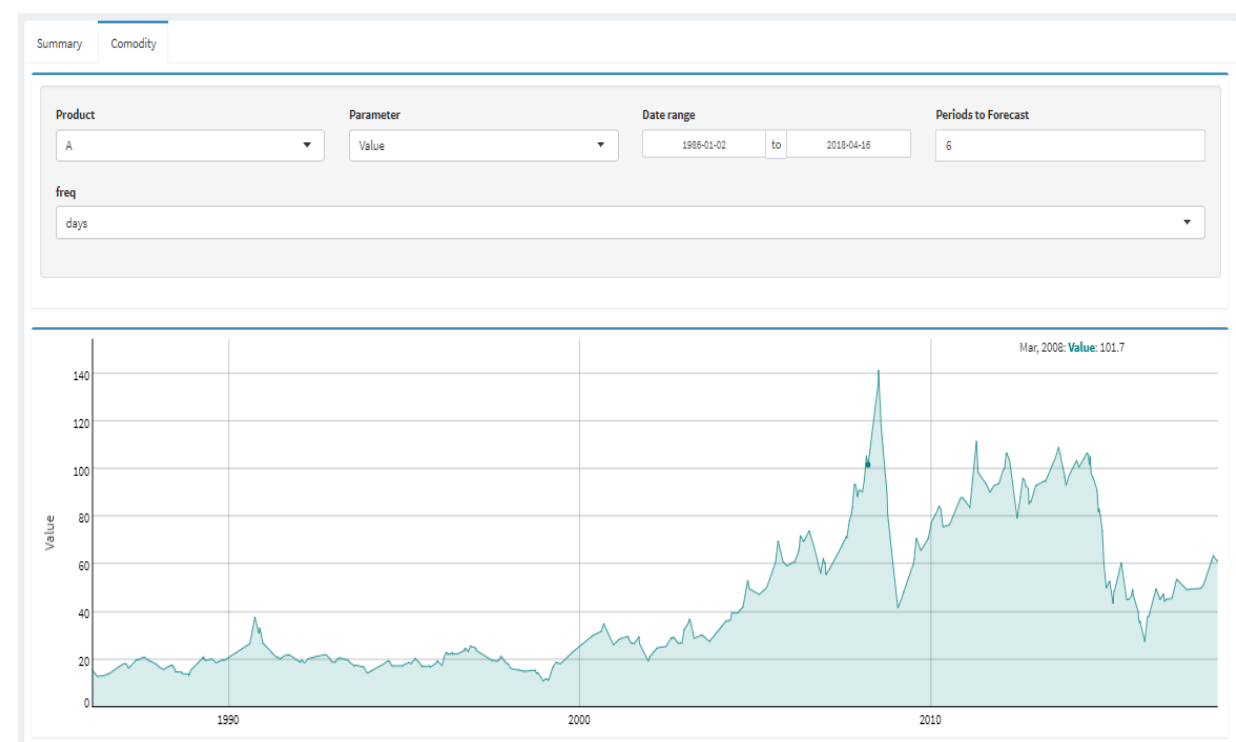

Gambar 12. Grafik Parameter Produk 
Gambar 13 merupakan bagian kedua dari output comodity yaitu tentang nilai ramalan beserta grafik. Metode statistik yang digunakan untuk meramal parameter-parameter penjualan adalah metode exponantial smoothing. Hasil yang diperoleh menunjukkan nilai nilai ramalan dan nilai-nilai selang kepercayaan suatu ramalan. Banyaknya nilai ramalan dapat ditentukan pada bagian pilihan Periods to Forecast yang ada pada bagian atas. Selain itu ditampilkan pula sebuah grafik interaktif yang memisahakan antara data aktual dan data ramalan.

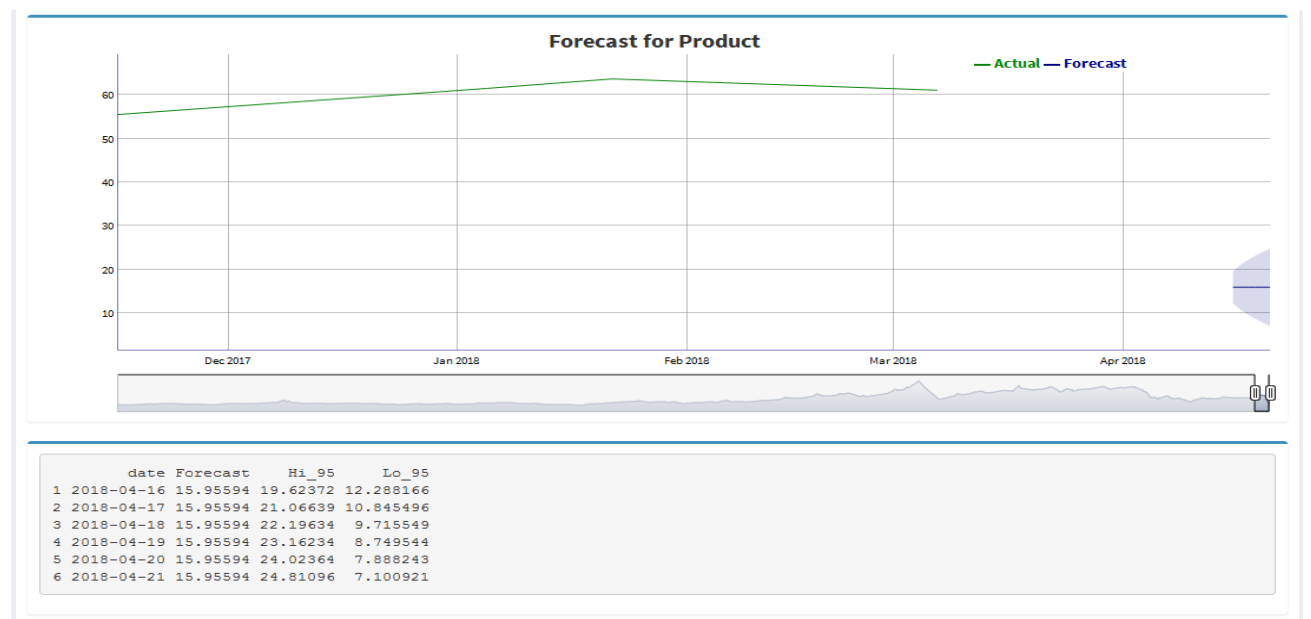

Gambar 13. Summary dan Grafik Sales Forecast

\section{Validasi Aplikasi}

Aplikasi telah divalidasi dengan cara membandingkan hasil output pada olah data R Studio (non-interface) dan hasil olah data aplikasi yang telah dibuat (interface) dengan Shiny. Gambar 14 menunjukkan hasil yang sama antara output pada olah data R Studio dan hasil olah data aplikasi interface baik yang offline maupun yang online.

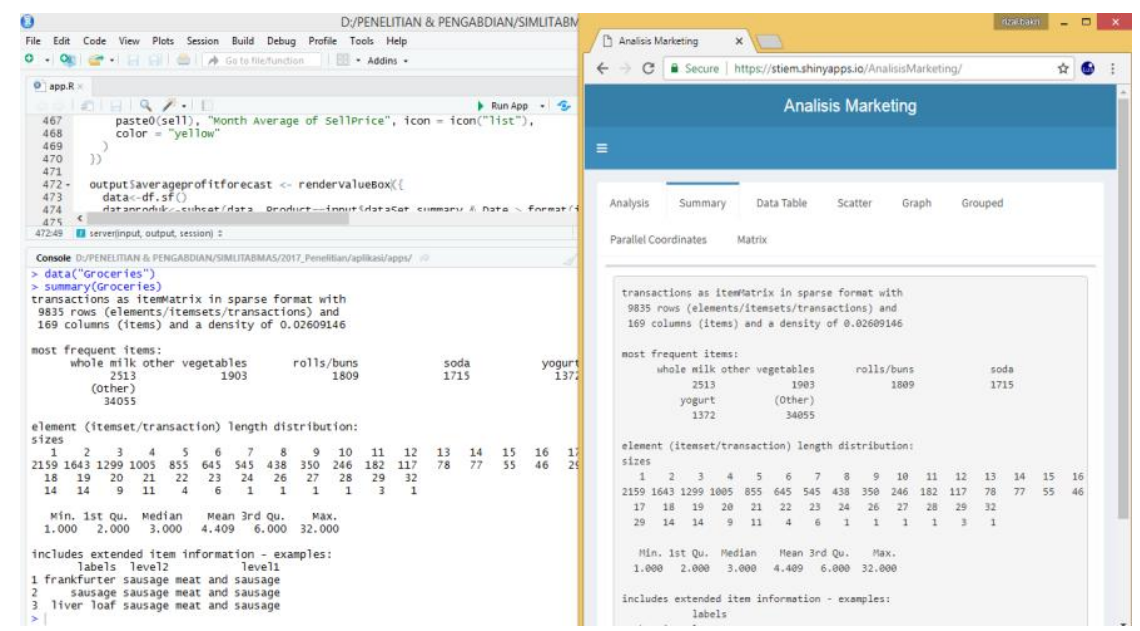

Gambar 14. Output Summary non-interface dan interface online 


\section{Rizal Bakri}

\section{Ardiansyah Halim}

Niken Probondani Astuti

\section{SIMPULAN DAN SARAN}

\section{Simpulan}

Sistem aplikasi ini telah dibuat untuk memudahkan para pelaku bisnis untuk mengoptimalkan penjualan. Sistem Aplikasi ini terdiri dari dua menu utama yaitu menu Market Basket Analysis dan Menu Sales Forecasting.

Market Basket Analysis digunakan untuk melihat pola belaja konsumen dan deskripsi lainnya. Manfaat dari Market Basket Analysis adalah para pelaku bisnis dapat melihat kebiasaan konsumen dalam membeli suatu produk. Manager suatu swalayan dapat mengatur dan mengoptimalakan posisi produk dalam rak berdasarkan hasil analisis perilaku konsumen menggunakan metode Market Basket Analysis.

Sales Forecasting digunakan untuk melihat deskripsi tentang parameter-parameter penjualan seperti jumlah ketersedian barang, jumlah barang terjual, keuntungan, rata-rata harga produk, rata-rata harga jual, dan produk-produk yang paling banyak terjual. Selain itu, di menu ini pelaku bisnis juga dapat melakukan peramalan terhadap parameterparameter penjualan untuk melakukan antisipasi atau manajemen keuangan dan stok barang.

\section{Saran}

Pemanfaatan metode kuantitatif perlu diperkenalkan ke para pelaku bisnis agar dapat memanfaatkan data penjualan yang tertumpuk dalam database. Aplikasi yang telah dibuat pada penelitian ini masih perlu dikembangkan termasuk metode peramalan yang digunakan hanya satu metode saja yaitu Exponantial Smoothing sehingga diharapakan perlu dilakukan penelitian selanjutnya yaitu memanfaatkan metode-metode peramalan lain dengan hasil ramal yang akurat. Selain itu, pada Menu Market Basket Analysis masih perlu dilakukan penelitian dengan mengembangkan metode baru seperti Ensemble Market Basket Analysis, dan lainnya.

\section{DAFTAR PUSTAKA}

Albion Reserach. 2007. Market Basket Analysis. http://www.albionresearch.com. Diakses pada tanggal [1 Juni 2017]

Belyi E, et. al. 2016. Combining Association Rule Mining and network Analysis for Pharmacosurveillance. The Journal of supercomputing 72 (5): 2014-2034. 
BPS. 2018 . Kota Makassar Dalam Angka: Makassar Municipality in figures. Katalog BPS : 1102001.7371.

Gunawan, dkk. 2015. Pengembangan Aplikasi Market Basket Analysis Menggunakan Algoritma Generalized Sequential Pattern Pada Supermarket. Yogyakarta: Seminar Nasional Aplikasi Teknologi Informasi (SNATi).

Hahsler M et. al. 2018. Mining Association Rules and Frequent Itemsets. R Version 1.6-1. URL : https://cran.r-project.org/web/packages/arules/arules.pdf.

Hashler M \& Chelluboina S. 2018. Visualizing Association Rules : Introduction to the R-extension Package arulesViz. $R$ version 1.3-1. URL : https://cran.rproject.org/web/packages/arulesViz/vignettes/arulesViz.pdf.

Hyndman R, et al. 2018. Forecasting Functions for Time Series and Linear Models. R version:

8.4. URL : https://cran.r-project.org/web/packages/forecast/forecast.pdf.

Ihaka R \& Gentleman R. 1996. R: A Language for Data Analysis and Graphics. Journal of Computational and Graphical Statistics 05 (03): 299-314.

Irliana N \& Vydia V. 2013. Market Basket Analysis Pada Perusahaan Retail Menggunakan Algoritma Apriori dan Sales Forecasting. Jurnal Informatika 11 (1): 13-22.

Mazzara S, et. al. 2017. CombiROC: An interactive web tool for selecting accurate marker combinations of omics data. Scientific Reports (Nature Publisher Group), 7, 45477. doi:http://dx.doi.org/10.1038/srep45477.

Pramita \& Tanuwiajaya. 2010. Penerapan Metode Exponential Smoothing Winter dalam Sistem Informasi Pengendalian Persediaan Produk dan Bahan Baku Sebuah Cafe. Yogyakarta: Seminar Nasional Informatika (semnasIF 2010).

Rizkiyani M. 2014. Penerapan Forecasting Methods untuk Meningkatkan Strategi dalam Sistem Penjualan Ponsel pada Sarang Cell Semarang. Semarang: Seminar Nasional Sistem Informasi Komputer. 


\section{Rizal Bakri}

\section{Ardiansyah Halim}

\section{Niken Probondani Astuti}

Samecka-cymerman, et. al. 2010. Market Basket Analysis: A new tool in ecology to describe chemical relations in the environment--A case study of the fern athyrium distentifolium in the tatra national park in poland. Journal of Chemical Ecology 36(9): 1029-34. doi:http://dx.doi.org/10.1007/s10886-010-9832-0.

Swastha, Basu, dan Irawan. 2008. Manajemen Pemasaran Modern. Yogyakarta: Liberty.

Chang, W \& Borges, B. 2018. Create Dashboard with 'Shiny'. R Version 0.7.0. URL : https://cran.r-project.org/web/packages/shinydashboard/shinydashboard.pdf.

Villaseñor-Derbez, J, et. al. 2018. A user-friendly tool to evaluate the effectiveness of no-take marine reserves. PLoS One, 13(1) doi:http://dx.doi.org/10.1371/journal.pone.0191821. 